\title{
Determining the distribution of triclosan and methyl triclosan in estuarine settings
}

\author{
Marina G. Pintado-Herrera, Eduardo González-Mazo, Pablo A. Lara-Martín* \\ Physical Chemistry Department, Faculty of Marine and Environmental Sciences, University of Cadiz, Spain
}

\section{H I G H L I G H T S}

- Simultaneous extraction of TCS and MTCS by SBSE-LD and PLE-in-cell-clean up.

- Analysis of estuarine sediment and water samples and from photodegradation assays.

- Distribution of analytes in estuaries depends on wastewater sources and tides.

- TCS can be both photodegraded or converted to MTCS in estuaries.

\section{A R T I C L E I N F O}

\section{Article history:}

Received 21 January 2013

Received in revised form 12 September

2013

Accepted 26 September 2013

Available online 5 November 2013

\section{Keywords:}

GC-MS

PLE

SBSE

Triclosan

Water

Sediment

\begin{abstract}
A B S T R A C T
We have developed a method for the analysis of two sewage-derived contaminants: triclosan (TCS), an antibacterial agent, and methyl triclosan (MTCS), a TCS metabolite. For solid samples (4 g), extraction and cleanup were integrated into the same step using pressurized liquid extraction (PLE) with in-cellclean-up ( $1 \mathrm{~g}$ of florisil). The extraction was performed using dichloromethane at $100{ }^{\circ} \mathrm{C}, 1500 \mathrm{psi}$ and 3 static extraction cycles of 5 min each. For water samples $(100 \mathrm{~mL})$, stir bar sorptive extraction-liquid desorption (SBSE-LD) was used. Bars were stirred for $10 \mathrm{~h}$ and analytes were later desorbed using acetonitrile. Finally, MTCS and a silylated derivative of TCS were determined by gas chromatography-mass spectrometry (GC-MS). Recovery experiments in water and sediments were performed and the results ranged from $67 \%$ to $78 \%$. Limits of detection (LODs) were $5 \mathrm{ng} \mathrm{L}^{-1}$ for TCS and $1 \mathrm{ng} \mathrm{L}^{-1}$ for MTCS, in water samples, and $0.1 \mathrm{ng} \mathrm{g}^{-1}$ for TCS and MTCS in solid samples. The method was applied then to determine the levels of these compounds in the estuary of Guadalete River (SW Spain). TCS and MTCS concentrations up to $9.6 \mathrm{ng} \mathrm{g}^{-1}$ in sediments and $310 \mathrm{ng} \mathrm{L}^{-1}$ in water were measured. Their distribution was strongly influenced by the presence of wastewater sources, treated and untreated, along the sampling area, where maximum concentrations were detected. Highest values were reached in the water column during low tides as the water volume in the estuary becomes lower.
\end{abstract}

(c) 2013 Elsevier Ltd. All rights reserved.

\section{Introduction}

Triclosan (TCS), 5-chloro-2-(2,4-dichlorophenoxy)phenol, is an antimicrobial and non-ionic fungicide with an extensive use in different personal care products (PCPs) (i.e. deodorants, toothpastes, and creams) and consumer products, such as toys. This compound has been used for more than 40 years and, nowadays, about 350 tons are consumed every year in Europe (Ciba Specialty Chemical, 1998). Application of this chemical is regulated by the European Economic Community Directive 76/768/EEC on Cosmetics (July 27th, 1976), which fixes the maximum TCS content in PCPs to $0.3 \%$. Recently, US Environmental Protection Agency (EPA) has

\footnotetext{
* Corresponding author. Address: Campus Río San Pedro s/n, Campus de Excelencia Internacional del Mar (CEI.MAR), 11510 Puerto Real, Cadiz, Spain. Tel.: +34956 016159; fax: +3495606040.

E-mail address: pablo.lara@uca.es (P.A. Lara-Martín).
}

suggested that TCS could cause potential human health effects, so they have started to conduct a review of TCS this year (http:// www.epa.gov/oppsrrd1/REDs/factsheets/triclosan_fs.htm). Additionally, it is also necessary to improve our knowledge on the environmental fate of TCS due to its possible bioaccumulation and toxicity in organisms, as well as the possibility of this compound promoting the predominance of antibiotic-resistant bacteria (Cottell et al., 2009).

TCS is introduced into aquatic systems after being used by forming part of urban and industrial wastewaters. Elimination of TCS is possible during secondary treatment in wastewater treatment plants (WWTPs) (Heidler and Halden, 2007). However, complete removal of this chemical is unlikely by using conventional methodologies for both wastewater treatment and drinking water production (Ternes et al., 2002). Optimum elimination rates (up to $90 \%$ ) are only achieved when membrane bioreactors are used (Bester, 2005). Using drinking water treatments such as chlorination 
may also improve the removal of the parent compound but formation of chlorinated byproducts that are even more toxic than TCS itself has been observed (Fiss et al., 2007). In most WWTPs, significant amounts of TCS are often accumulated in sewage sludge, the remaining fraction being biologically degraded and/or discharged into the environment through effluents. This compound could also end up in the terrestrial environment as concentrations of $4 \mathrm{ng} \mathrm{g}^{-1}$ have been reported in farm soils amended with biosolids (Lozano et al., 2010).

Concentrations of TCS have been measured in aquatic systems in both aqueous and solid samples (Zhao et al., 2010). Levels of dissolved TCS, however, can change depending on the season of the year and the sampling depth (Lindström et al., 2002). Much higher values are often found in sediments (up to $130.7 \mu \mathrm{g} \mathrm{kg}^{-1}$ ) according to Agüera et al. (2003), as sorption capacity of TCS is relatively high due to its hydrophobicity (log $K_{o w} 4.7$ (Zhao et al., 2010), log $K_{o c} 4.3$ (Chen et al., 2011)). Once buried in the sediment column, anaerobic degradation of this compound by any dechlorination process has not been observed, such as it happens with the antimicrobial triclocarban (Miller et al., 2008) and other related compounds. Most TCS undergoes photodegradation instead during its transport along the water column (Lindström et al., 2002). Biotransformation is also possible via TCS methylation, which produces methyl triclosan (MTCS), a more hydrophobic and nonphotodegradable compound that may be accumulated by some aquatic organisms (Balmer et al., 2004). Available data on MTCS distribution in the environment is still scarce, mostly focused on wastewater treatment plants and freshwater (Balmer et al., 2004; Sánchez-Brunete et al., 2010) and, to our knowledge, there is only a previous manuscript that reports concentrations of this metabolite in sediments (Fernandes et al., 2011).

Determination of TCS and its metabolite, MTCS, in environmental samples have been carried out by different analytical methods. In general terms, and due to the low concentrations of these chemicals and many other PCPs in environmental matrices, analytes need to be extracted and pre-concentrated before analysis. In this sense, solid phase extraction (SPE) is one of the most commonly used techniques, being also easily automated (Kuster et al., 2008; Cueva-Mestanza et al., 2008; Azzouz et al., 2010) and more environmentally friendly than conventional liquid liquid extraction (LLE) (Bester, 2005). The use of sorptive techniques such as solidphase microextraction (SPME) (Canosa et al., 2005) and stir bar sorptive extraction (SBSE) (Silva and Nogueira, 2008; Pedrouzo et al., 2010) for processing aqueous samples has increased over the last years. Their main advantages are solventless sample enrichment, minimal manipulation of the sample (therefore reducing the risk of contamination), reduction of the time of sample preparation, and reuse of the polymer fiber. Once analytes are extracted from the sample, SBSE, which is the technique that we have chosen to optimize for TCS and MTCS analysis in this work, requires a desorption step which is often accomplished thermally (TD). In this case, we have focused on developing a new method that relies on liquid desorption (LD) instead, being suitable for those laboratories where a thermo-desorption unit is not available. Regarding the extraction of TCS and MTCS from solid samples, several different techniques such as Soxhlet extraction (Buth et al., 2010), matrix solid-phase dispersion (Sánchez-Brunete et al., 2010) or pressurized liquid extraction (PLE) (Cantwell et al., 2010), have been used. Later purification and preconcentration of the extracts is often required; SPE is one of the techniques more widely used for this purpose (Cueva-Mestanza et al., 2008 and Chu and Metcalfe, 2007). Recently, SBSE also has been applied in soil samples (Casas-Ferreira et al., 2011), for the extraction of some organic compounds, minimizing manipulation of the extracts. We have gone a step beyond by combining PLE with simultaneous in-cell clean-up purification of the extracts, avoiding further manipulation of the sample (Canosa et al., 2007). Finally, determination of both target compounds, TCS and MTCS, can be performed by gas chromatography (GC-MS) (Sánchez-Brunete et al., 2010 and Canosa et al., 2007) or liquid chromatographymass spectrometry (LC-MS) (Zhao et al., 2010). Analyzes of TCS by LC coupled to tandem mass spectrometry (Chu and Metcalfe, 2007; Pedrouzo et al., 2010) or ultra violet detectors (UV) (Cueva-Mestanza et al., 2008) have been reported, although most authors usually employ GC instead as higher resolution and lower detection limits are achieved.

The goals of this work are: (a) the development and optimization of an analytical method that allows simultaneous determination of TCS and MTCS in environmental matrices using PLE - in-cell clean-up and SBSE-LD techniques followed by later GC-MS analysis, and (b) the application of this method for the determination of the presence of this biocide and its transformation product in an urbanized estuarine setting (Guadalete River, SW Spain).

\section{Materials and methods}

\subsection{Chemicals}

Methanol (MeOH), dichloromethane (DCM), acetonitrile (ACN) and ethyl acetate (EA) HPLC grade were purchased from Scharlau (Barcelona, Spain). TCS and MTCS were acquired from Sigma Aldrich (Barcelona, Spain). ${ }^{13} \mathrm{C}_{12}$-methyl triclosan $\left({ }^{13} \mathrm{C}_{12}\right.$-MTCS) and triclosan-d3 (TCS-d3) were purchased from Dr. Ehrenstorfer $\mathrm{GmbH}$ (Augsburg, Germany). Standard solutions of the target compounds were prepared in methanol and stored in the dark at $-20^{\circ} \mathrm{C}$. N(tert-butyldimethylsilyl)-N-methyltrifluoroacetamide (MTBSTFA) from Sigma Aldrich (Barcelona, Spain) was used as derivatizing agent. Several sorbents (florisil, alumina and silica) were provided by Varian (Madrid, Spain). HPLC grade water was purchased from J.T. Baker (Serviquimia, Barcelona, Spain), whereas artificial seawater was prepared according to Zaroogian et al. (1969). Sodium sulfate anhydrous and salts were purchased from Panreac (Barcelona, Spain). $10 \mathrm{~mm} \times 0.5 \mathrm{~mm}$ and $20 \mathrm{~mm} \times 0.5 \mathrm{~mm}$ (length $\times$ film thickness) commercial polydimethylsiloxane (PDMS) stir bars and a 15 position magnetic stirrer were purchased from Gerstel (Mulheim a/d Ruhr, Germany).

\subsection{Extraction procedures}

Analytes were extracted from the water samples by SBSE, a technique that was developed by Baltussen et al. (1999). The polymer used was polydimethylsiloxane (PDMS), which shows affinity by those compounds having $\log K_{o w}$ coefficients higher than 2 (Prieto et al., 2010). The influence of the extraction time, size bar and ionic strength was evaluated by means of recovery experiments (percent of standard added to sample recovered during extraction) where aqueous samples ( $100 \mathrm{~mL}$ of HPLC water) were spiked with $5 \mu \mathrm{g} \mathrm{L}^{-1}$ of TCS and MTCS. Surrogates, TCS- $\mathrm{d}_{3}$ and ${ }^{13} \mathrm{C}_{12}-\mathrm{MTCS}$ ( $5 \mu \mathrm{g} \mathrm{L}^{-1}$ each), were added to environmental samples to determine possible fluctuations during the extraction procedure. Once the method was optimized, PDMS bars (twisters) were placed in amber-glass flasks containing the aqueous samples ( $100 \mathrm{~mL}$ each) and were stirred at $900 \mathrm{rpm}$ (these parameters were previously optimized by our group in others works, (Pérez-Carrera et al., 2007), and others works (Giordano et al., 2009) during $10 \mathrm{~h}$ at room temperature and darkness conditions). Later, analytes were chemically desorbed from the PDMS bars by immersing them into a compatible solvent ( $1.5 \mathrm{~mL}$ of acetonitrile).

This desorption step can be accelerated by applying temperature or sonication. In our case, sonication was selected (30 min). Finally, bars were removed and the solvent was evaporated to dryness and redissolved in $200 \mu \mathrm{L}$ of ethyl acetate. Analyte losses 
were not detected during the evaporation process due to the low vapor pressure of these compounds $\left(5.2 \times 10^{-6} \mathrm{~mm} \mathrm{Hg}\right.$ at $25^{\circ} \mathrm{C}$ ) (Zhao et al., 2010). To evaluate background contamination, blank assays were also performed by extracting HPLC water and artificial seawater, and their signals were subtracted to real samples.

Extraction of TCS and MTCS from sediment samples was achieved by PLE, using an accelerated solvent extractor ASE 200 (Dionex, USA). Briefly, dried and milled solid samples (4 g) were mixed with $16 \mathrm{~g}$ of sodium sulfate (dispersant agent) and were placed into steel extraction cells $(22 \mathrm{~mL})$. The influence of extraction temperature, extraction solvent and clean-up sorbent was evaluated. Under optimal conditions, dichloromethane was used as solvent, in three static extraction cycles of $5 \mathrm{~min}$, at $100^{\circ} \mathrm{C}$ and 1500 psi with a purge time of $60 \mathrm{~s}$ ( $t<20 \mathrm{~min}$ ). Purification of the extracts was performed simultaneously to the extraction (in-cell clean-up) by adding sorbent in the cell. The extraction cells contained, from the bottom to the top, two cellulose filters, $1 \mathrm{~g}$ of sorbent, a cellulose filter and $20 \mathrm{~g}$ of sample with dispersant. Finally, extracts $(30 \mathrm{~mL})$ were evaporated to dryness using a Syncore Polyvap (Büchi, Switzerland) and re-dissolved in $200 \mu \mathrm{L}$ of ethyl acetate. Optimization experiments were carried out by spiking not polluted sediments with $1 \mu \mathrm{g} \mathrm{g}^{-1}$ of the target compounds $24 \mathrm{~h}$ before the extraction and stored at $4{ }^{\circ} \mathrm{C}$. Surrogates, TCS $-\mathrm{d}_{3}$ and ${ }^{13} \mathrm{C}_{12}$-MTCS ( $1 \mu \mathrm{g} \mathrm{g}^{-1}$ each), were added to environmental samples to account for losses during the extraction procedure. Blanks assays were also performed using non-polluted sediments spiked with surrogates.

\subsection{Instrumentation}

Separation and detection of target compounds were performed by gas chromatography-mass spectrometry (GC-MS) using a Thermo Fisher Voyager GC 8000 system. $10 \mu \mathrm{L}$ of MTBSTFA were added to the samples before injection. A HP-5MS column (30 $\mathrm{m} \times 0.25 \mathrm{~mm}$ i.d. $\times 0.25 \mu \mathrm{m}$ film thickness of $5 \%$ phenyl, $95 \%$ polydimethylsiloxane) was used for the capillary gas chromatography analysis, employing helium as carrier gas (flow $=1 \mathrm{~mL} \mathrm{~min}^{-1}$ ). The injection port temperature was $250{ }^{\circ} \mathrm{C}$. Two $\mu \mathrm{L}$ of sample were injected in splitless mode (solvent delay $=4 \mathrm{~min}$ ). The column temperature ramp was as follows: $80^{\circ} \mathrm{C}$ for $1 \mathrm{~min}$, ramped at $50{ }^{\circ} \mathrm{C} \mathrm{min}^{-1}$ to $130^{\circ} \mathrm{C}$, then at $5^{\circ} \mathrm{C} \mathrm{min}^{-1}$ to $240{ }^{\circ} \mathrm{C}$ and finally at $15^{\circ} \mathrm{C} \mathrm{min}^{-1}$ to $300^{\circ} \mathrm{C}$, held for $5 \mathrm{~min}$. The electron impact source and quadrupole analyzer temperatures were of 250 and $150{ }^{\circ} \mathrm{C}$, respectively. The mass detector acquired in selected ion-monitor- ing (SIM) mode using electron impact ionization (EI) at $70 \mathrm{eV}$. Concentrations of analytes in the samples were determined by measuring the peak areas of the fragments and using calibration curves for each component. For water samples, calibration curves were previously prepared by spiking water aliquots with TCS and MTCS from $0.02 \mu \mathrm{g} \mathrm{L}^{-1}$ to $20 \mu \mathrm{g} \mathrm{L}^{-1}$ and extracting the analytes using PDMS bars. For solid samples, external calibration curves $\left(0.02 \mu \mathrm{g} \mathrm{g}^{-1}\right.$ to $\left.2.5 \mu \mathrm{g} \mathrm{g}^{-1}\right)$ were used instead. The precision of the method was expressed as the relative standard deviation (RSD) of replicate measurement. The reproducibility and repeatability of the method were also evaluated by performing three successive injections of the same sample and by re-analyzing a same batch of samples 2 weeks after their first analysis. Limits of detection (LODs) were established for signal-to-noise ratios of 3 as the minimum detectable signals.

\subsection{Sampling and laboratory experiments}

The study area was located in the province of Cadiz (Southwest Spain), along the estuary of the Guadalete River (Fig. 1), which receives numerous wastewater discharges from urban, agricultural and industrial origins. There is a previous study (Lara-Martín et al., 2006) that identifies the WWTP located at station G12 as one of the most important sources of organic contaminants in the area. This WWTP collects domestic wastewater from a population higher than 200000 inhabitants (Jerez de la Frontera) and the sludges generated in the plant are often reused as fertilizer by local farmers. Thirteen sediment samples were taken along the estuary (stations G1 to G13), collecting the topmost $10 \mathrm{~cm}$ layer by means of a Van Veen grab. Samples were transported at $4{ }^{\circ} \mathrm{C}$ to the laboratory, where they were frozen at $-20^{\circ} \mathrm{C}$. Later, sediments were dried at $50{ }^{\circ} \mathrm{C}$ and milled using a zirconium oxide ball mill. Organic carbon content was determined in these samples using the method described by El Rayis (1985). Additionally, surface water samples were taken at station W1 during a tidal event ( $12 \mathrm{~h})$. El Puerto de Santa María (100000 inhabitants) is located nearby this sampling station and uncontrolled wastewater discharges have been found to take place occasionally from this town. Water samples were collected in clean amber-glass bottles $(250 \mathrm{~mL})$, filtered on site $(0.45 \mu \mathrm{m})$ and placed in a cooler at $4{ }^{\circ} \mathrm{C}$ prior to analysis, which was carried out within $24 \mathrm{~h}$.

Additionally, two photodegradation experiments were carried out on a Suntest CPS simulator. The intensity of the lamp was set to $550 \mathrm{~W} \mathrm{~m}^{-2}$. The temperature in the chamber was maintained

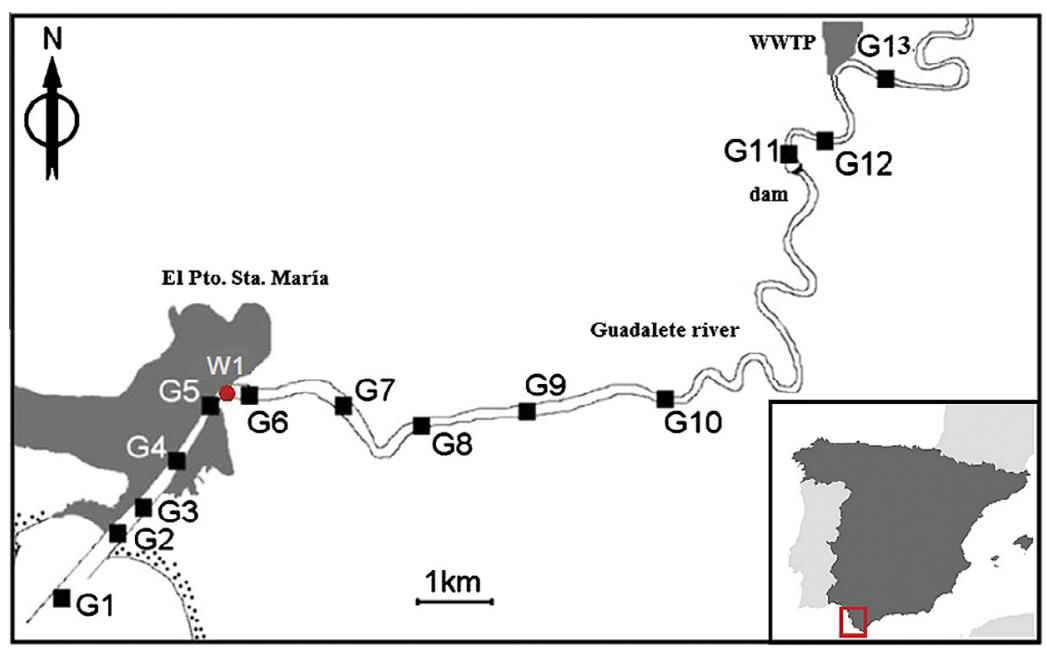

Fig. 1. Map showing the location of the sampling area and the sampling stations. 
at $25 \pm 1{ }^{\circ} \mathrm{C}$. Duration of the experiments was $60 \mathrm{~min}$. Briefly, $10 \mathrm{~mL}$ glass quartz tubes containing artificial seawater were spiked with $5 \mu \mathrm{g} \mathrm{L}{ }^{-1}$ of TCS or MTCS, depending on the experiment. There was also a control experiment consisting of glass tubes spiked with analytes but covered by aluminum foil to avoid photodegradation. Samples were taken at regular intervals and extracted in the darkness using SBSE. No degradation was observed in the control experiment.

\section{Results and discussion}

\subsection{SBSE-LD optimization}

Taking into account available information on SBSE method development (Pérez-Carrera et al., 2007), we decided to start by setting some parameters to reduce the number of experiments. Thus, agitation speed of PDMS bars was set to $900 \mathrm{rpm}$ as higher speeds may reduce lifetime of the stir bars (Giordano et al., 2009). Liquid desorption (LD) time was set to $30 \mathrm{~min}$ and sample volume to $100 \mathrm{~mL}$. The desorption solvent volume was set to $1.5 \mathrm{~mL}$ to guarantee the full immersion of the bars in $2 \mathrm{~mL}$ amber-glass vials. Optimization of the extraction of TCS and MTCS from aqueous samples was carried out then by testing the effect of different parameters affecting SBSE-LD efficiency. These parameters were: PDMS bar size, extraction time, ionic strength, and desorption solvent. All the experiments were performed at room temperature $\left(25^{\circ} \mathrm{C}\right)$, by triplicate and darkness, by spiking water samples at $5 \mu \mathrm{g} \mathrm{L}^{-1}$ of TCS and MTCS.

First, two PDMS bar sizes were tested (10 and $20 \mathrm{~mm}$ length, extraction time $=10 \mathrm{~h}$ ). This is a key parameter because extraction is an equilibrium process between the aqueous sample and the bar (Prieto et al., 2010), being greatly affected by the total mass of PDMS. After testing both sizes, $20 \mathrm{~mm}$ length stir bars (coated with $126 \mu \mathrm{L}$ of PDMS) were selected for further experiments as this size provided a better extraction capacity (up to $80 \%$ for MTCS and $30 \%$ for TCS) than $10 \mathrm{~mm}$ length bars. $20 \mathrm{~mm}$ length bars are often used by most authors when extracting sample volumes greater than $100 \mathrm{~mL}$, whereas the use of smaller bars is preferred for low volume samples $(10 \mathrm{~mL}$ or less) such as pore water (Pérez-Carrera et al., 2007). Next, the liquid desorption step and the influence of the ionic strength were optimized by testing different organic solvents (MEOH, EA and ACN) and salinity values ( 0 and 35$)$, respectively. Results are shown in Fig. 2. First, notable differences were detected when comparing the extraction recovery percentages for both analytes. These values were always much higher for MTCS than for TCS, which can be attributed to the higher hydrophobicity ( $\log K_{o w} 5.2$ for MTCS (Balmer et al., 2004) vs 4.7 for TCS) and, therefore, greater affinity of MTCS for the PDMS polymer. This fact has also been observed for other organic compounds (Pérez-Carrera et al., 2007) such as polycyclic aromatic hydrocarbons (PAHs), which show improved extraction efficiencies as the number of benzene rings in their structures increases. On the other hand, differences in desorption efficiencies were minimal (below 5\%) for both analytes when moving from one solvent to another. There was, however, a decrease of about $10 \%$ in the extraction efficiency of TCS when comparing results obtained from HPLC water with those from artificial seawater. According to Quintana et al. (2007), this could be due to the viscosity of the sample increasing as salinity is higher, which may difficult the extraction process. Presence of salts has been already proven to affect to the extraction efficiency of many hydrophobic organic pollutants when using PDMS bars (Beltran et al., 1998; Giordano et al., 2009). Another possible explanation is that deprotonation of TCS is enhanced when $\mathrm{pH}$ of the medium is higher than $\mathrm{pKa}$ for this compound (7.9) (Chen et al., 2011) (pH values for artificial seawater and HPLC
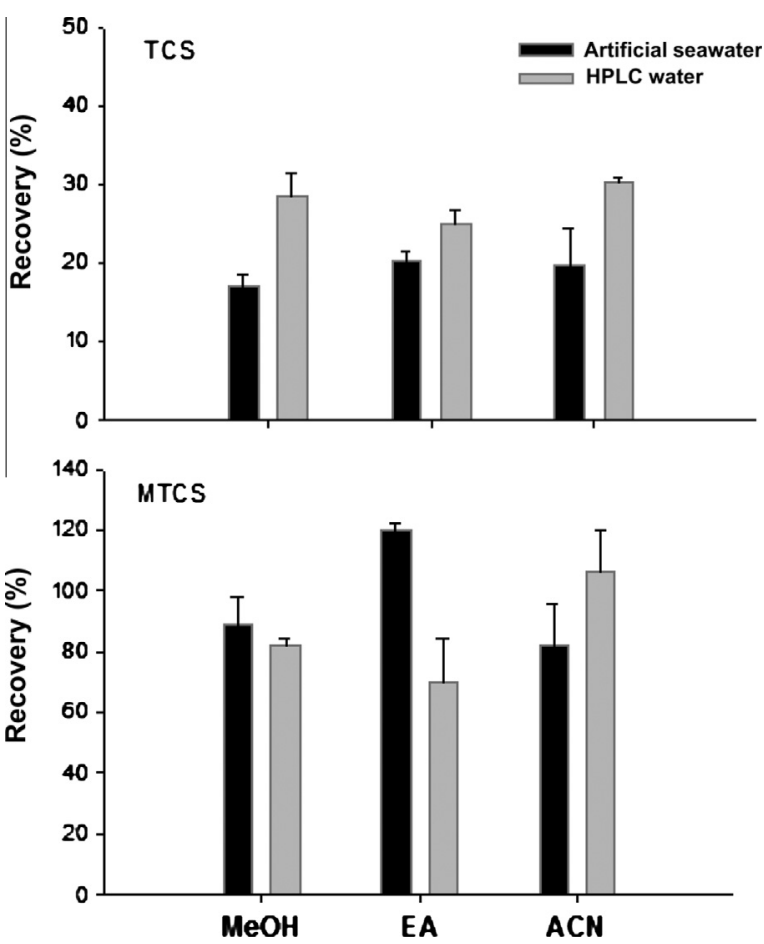

Fig. 2. Influence of the extraction solvent during SBSE-LD in two different aqueous matrices (HPLC water and artificial seawater) for TCS and MTCS.

water were 8.09 and 6.7, respectively), therefore increasing the solubility of this analyte. Differences in the recovery percentages when using different solvents and salinities became more noticeable for MTCS (occasionally greater than 20\%). Taking into account that TCS was the analyte showing worse extraction efficiencies, ACN was selected at the end as extraction solvent because it presented a slightly higher capacity to release TCS from the bars in both matrices (HPLC water and seawater).

Last, agitation time was optimized. This is a key parameter because it is necessary that bars are kept in contact with the samples until the equilibrium is reached so the accuracy and repeatability of measurements improve (Prieto et al., 2010). Agitation time was optimized by stirring the samples at different time periods $(0,0.5,1,2,4,6,8,10$ and $24 \mathrm{~h})$. Results (Fig. 3) show that both analytes reached the highest extraction efficiencies after an exposure time of $8 \mathrm{~h}$. Afterwards, there was a slight decrease (less than 10\%) (Gilart et al., 2013). PDMS bars can be retrieved anytime

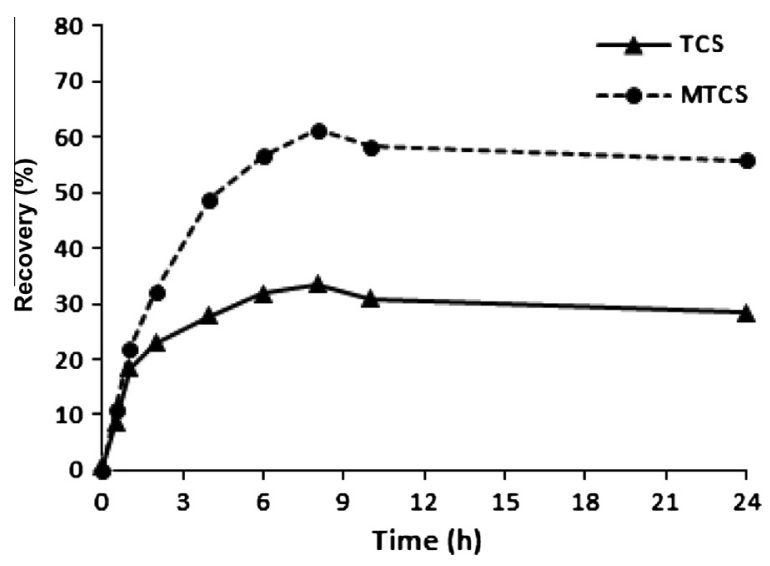

Fig. 3. Influence of the extraction time during SBSE-LD for TCS and MTCS 
between 8 and $24 \mathrm{~h}$ to ensure that the water-PDMS equilibrium has been achieved. As an example, for a fixed sample volume of $100 \mathrm{~mL}, 14 \mathrm{~h}$ extracting periods have been previously used by other authors screening for different organic contaminants (Pérez-Carrera et al., 2007). It may be possible to accelerate this process and retrieve bars after only $2 \mathrm{~h}$ if lower sample volumes are employed, but worse limits of detection (LODs) are achieved (Silva and Nogueira, 2008).

\subsection{PLE optimization}

Extraction of sediments was carried out by PLE after optimization of two key parameters: extraction solvents and temperature. We fixed the following parameters according to previous works (Lara-Martín et al., 2006): three extraction cycles of 5 min each, $4 \mathrm{~g}$ of sample, and a pressure value of $1500 \mathrm{psi}$ (enough to avoid solvents boiling). The extraction performance was tested by spiking non-polluted sediments with $5 \mathrm{ng} \mathrm{g}^{-1}$ of the target compounds and waiting $24 \mathrm{~h}$ before extraction at $4{ }^{\circ} \mathrm{C}$ to reach equilibrium. All the experiments were carried out by triplicate.

First, extraction temperature was optimized. Four different temperature values were tested: $25^{\circ} \mathrm{C}, 50^{\circ} \mathrm{C}, 100^{\circ} \mathrm{C}$ and $150^{\circ} \mathrm{C}$. Results (Fig. 4a) showed that there was an increase in the extraction efficiency at higher temperatures, especially when moving from $25^{\circ} \mathrm{C}$ (room temperature) to $100{ }^{\circ} \mathrm{C}$. This is a consequence of an increase in the mass transfer rate and the solubility of the compounds in the solvent (Lara-Martín and González-Mazo, 2009). Thus, recovery percentages improved from 35\% and 65\% for TCS and from $44 \%$ to $160 \%$ for MTCS. Values were significantly above $100 \%$ for MTCS when temperature was $100^{\circ} \mathrm{C}$, which can be attributed to the co-extraction of matrix interferences. There was a decrease in the extraction efficiency for both analytes at higher temperatures $\left(150^{\circ} \mathrm{C}\right)$. This phenomenon has been explained by several authors as a consequence of degradation (Göbel et al., 2005) and/or volatilization (Petrovic et al., 2002) of target compounds. PLE temperature was therefore set at $100{ }^{\circ} \mathrm{C}$ during the following experiments, which is a value often employed for an efficient extraction of a wide variety of organic contaminants (Agüera et al., 2003; Lara-Martín et al., 2006).

Three different extraction solvents showing different polarities (DCM $<\mathrm{EA}<\mathrm{MeOH}$ ) were tested for PLE of TCS and MTCS. These solvents have been previously used for TCS extraction from solid matrices, mainly WWTP sludge (Agüera et al., 2003; Canosa et al., 2007). Results are shown in Fig. 4b. The highest recoveries corresponded to DCM for both compounds, reaching values of $73 \%$ for TCS and $160 \%$ for MTCS. The highest extraction efficiency of this solvent compared to $\mathrm{MeOH}$ and EA (both showing higher polarities than DCM) can be explained if we consider than both TCS and MTCS are relatively highly hydrophobic compounds (log $K_{\text {ow }}>4$ ) that become strongly sorbed onto sediment surfaces. $\mathrm{MeOH}$ is often employed in PLE to extract more polar compounds such as surfactants (Lara-Martín et al., 2006), so DCM was selected instead for an optimum extraction of analytes in this work.

Last, we decided to add a clean-up stage in order to remove as many matrix interferences as possible before analysis of samples by GC-MS. Most authors often carry out offline purification of sludge and/or sediment extracts using silica (Agüera et al., 2003), HLB (Lozano et al., 2010), florisil (Wu et al., 2007) or other commercially available solid phase extraction (SPE) cartridges. In our case, we have preferred saving time and reducing sample manipulation by introducing these sorbents inside the PLE extraction cells, a technique known as in-cell clean-up that yields recoveries similar to those obtained by conventional offline SPE (Buth et al., 2010). Three different sorbents were selected (silica, alumina and florisil), placing $1 \mathrm{~g}$ inside the extraction cells between two cellulose filters and above the sample and dispersant mixture. Clean-up experiments were performed at $100{ }^{\circ} \mathrm{C}$ and DCM was used as solvent. Results (Fig. 4c) show that both target compounds were still efficiently extracted by PLE as well as interferences were removed in the case of MTCS (recovery percentages were below 100\% after in-cell clean-up). There were slight differences when comparing between different sorbents, although florisil was selected at the end at it showed better recovery percentages than the rest (70\% and $77 \%$ for TCS and MTCS, respectively, which are comparable to values previously reported by Agüera et al. (2003).

\subsection{Analysis of target compounds by GC-MS}

Separation, identification and quantification of analytes were performed using gas chromatography-mass spectrometry (GCMS). First, we conducted a full scan analysis $(m / z 50-500)$ to obtain the retention times and mass spectra of the analytes. Afterwards, samples were analyzed in SIM mode to achieve lower limits of detection. Fig. 5a displays a total ion current chromatogram showing that TCS signal was much lower than that for MTCS. The TCS chromatographic peak was also poorly resolved (tailing) due to the presence of a hydroxyl group in the structure of this compound. A derivatization step was required to solve this issue. Two different volumes of MTBSTFA were tested (10 and $20 \mu \mathrm{L}$ ). No differences were observed, therefore $10 \mu \mathrm{L}$ of MTBSTFA were added to the final extract and left $30 \mathrm{~min}$ at room temperature prior to GC-MS analysis. Once TCS was derivatized, signal intensity increased by a factor of 20 (Fig. 5b) and retention time was longer due to the higher molecular weight of the tert-butyldimethylsilyl

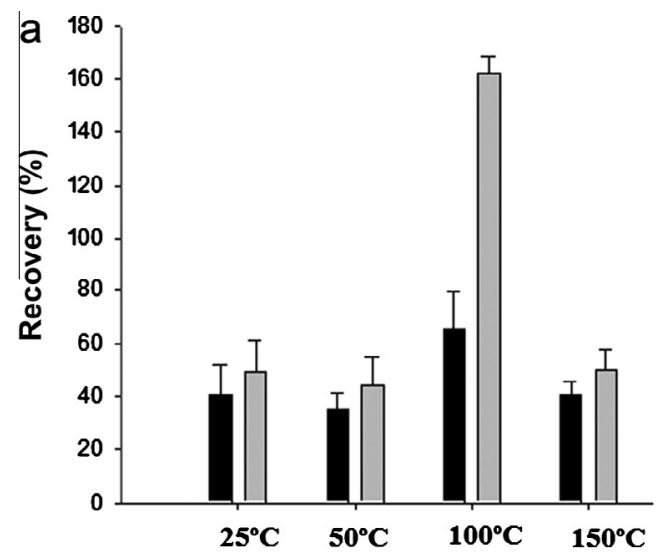

b

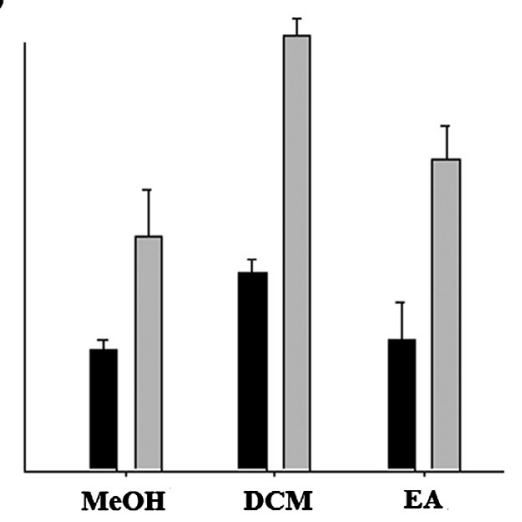

C

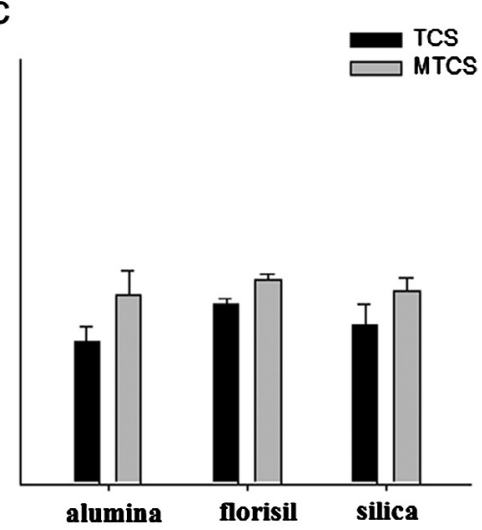

Fig. 4. Influence of (a) the extraction temperature, 9 (b) the extraction solvent, and (c) the in-cell clean-up sorbent during PLE of TCS and MTCS. 


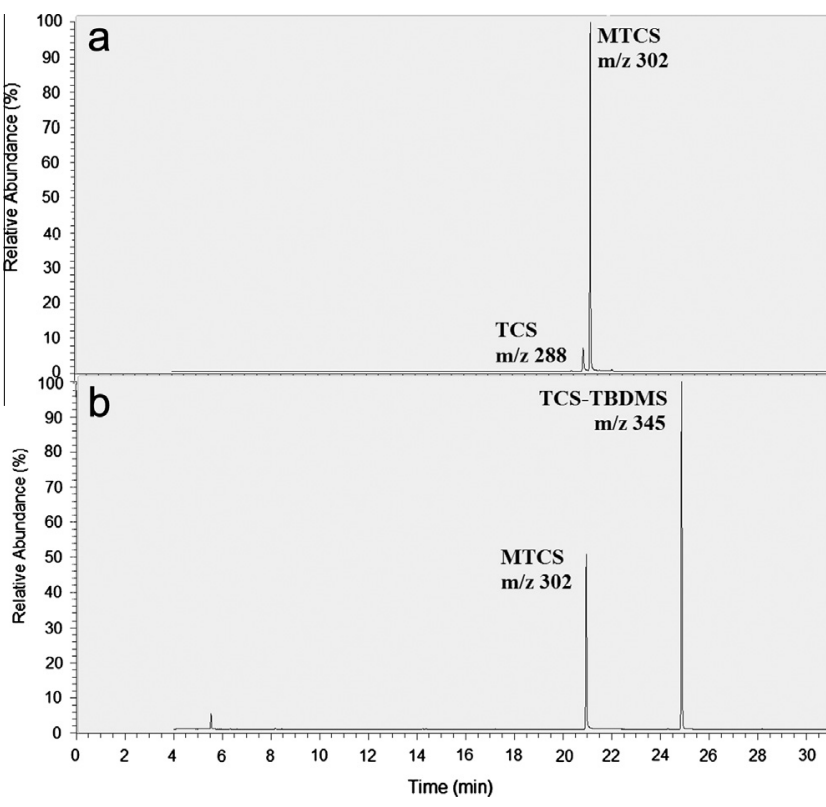

Fig. 5. Total ion current (TIC) chromatograms for TCS and MTCS before (a) and after (b) derivatization using MTBSTFA.

derivates (TBDMS) of TCS. The chromatographic peak was also better resolved, whereas MTCS was not affected by the derivatization agent because it does not show any hydroxyl group in its structure. Finally, two ions were selected in SIM mode for the identification and confirmation of the target compounds $(\mathrm{m} / \mathrm{z} 345$ and 347 at $24.86 \mathrm{~min}$ for TCS-TBDMS, and 302 and 304 at $20.98 \mathrm{~min}$ for MTCS) (Table 1). Underivatized TCS was also quantified and represented less than $3 \%$ of the total amount.

\subsubsection{Analytical performance of the method}

Calibration curves were showing determination coefficients $\left(R^{2}\right)$ higher than 0.99 (Table 1 ) were constructed for measuring TCS-TBDMS and MTCS concentrations in both water and sediment samples. These concentrations were corrected by comparing the signal intensities of the surrogates (TCS- $\mathrm{d}_{3}$ and ${ }^{13} \mathrm{C}_{12}$-MTCS) in real samples with those in pure standards. Limits of detection were $5 \mathrm{ng} \mathrm{L}^{-1}$ and $3 \mathrm{ng} \mathrm{L}^{-1}$ for TCS and MTCS, respectively, in water samples, and $0.1 \mathrm{ng} \mathrm{g}^{-1}$ in solid samples. Overall precision of the analytical technique, reproducibility and repeatability were good, showing relative standard deviations (RSDs) below 20\% for both analytes (Table 1). The behavior of these compounds was linear in the studied range, from $0.02 \mu \mathrm{g} \mathrm{g}^{-1}$ to $2.5 \mu \mathrm{g} \mathrm{g}^{-1}$ for sediment samples, and from $0.02 \mu \mathrm{g} \mathrm{L}^{-1}$ to $20 \mu \mathrm{g} \mathrm{L}^{-1}$ for water samples. Surrogates were added for studying of the matrix effect, which could affect the retention time and signal intensity of the analytes, but this fact was found out to be negligible in our samples.

\subsection{Case study: monitoring the occurrence of TCS and MTCS in an estuarine setting}

The method developed here was applied to the analysis of water and sediment samples from the estuary of Guadalete River
(SW Spain) (Fig. 1). Surface sediment samples were taken from 13 different stations (G1 to G13), whereas 11 surface water samples were collected at station W1 during a tidal event. Salinity values in water samples were between 34 and 39, and concentration of suspended solids were between 10 and $49 \mathrm{mg} \mathrm{L}^{-1}$, being higher when the tide was high. Results for TCS and MTCS concentrations are shown in Table 2. TCS concentrations in water ranged between 27 and $310 \mathrm{ng} \mathrm{L}^{-1}$, depending on the sampling time. These values are within the same order of magnitude than those previously reported in different aquatic systems (Quintana et al., 2007; Kawaguchi et al., 2008; Zhao et al., 2010). Tides are clearly affecting the distribution of TCS in the estuary: lowest TCS levels were reached when seawater entered the river (flooding), causing a dilution effect, whereas concentrations rose during ebbing. Thus, minimum values ( $\left.<100 \mathrm{ng} \mathrm{L}^{-1}\right)$ were detected when tide was high (10:30 h$15: 30 \mathrm{~h}$ ) and maximum values when tide was low (9:30 h and 17:30 h). The same trend was observed for MTCS, the main TCS metabolite, showing concentrations from 27 to $190 \mathrm{ng} \mathrm{L}^{-1}$. Presence of MTCS implies that triclosan is biologically transformed. However, this antimicrobial can be also removed from the water column by means of photodegradation processes (Kantiani et al., 2008). In this sense, we run a photodegradation experiment using both chemicals, TCS and MTCS. Kinetic profiles showing the removal of these target compounds in water by sunlight photolysis are displayed in Fig. 6. TCS was rapidly photodegraded (halflife $=16 \mathrm{~min}$ ), whereas MTCS was stable, which is in agreement with recent previous assays performed using lake water (Lindström et al., 2002). After $60 \mathrm{~min}$, the percentage of non-degraded TCS was only $7.5 \%$, where it was higher than $90 \%$ for MTCS. In spite of being quickly photodegraded, triclosan was detected often at higher concentrations than MTCS in every water sample. This implies the existence of a continuous input of TCS in the estuary. In this sense, the WWTP located at station G12 is reported to be the main source for sewage derived contaminants in this sampling area. Previous studies have confirmed the presence of organic compounds such as phenanthrene ( $344 \mathrm{ng} \mathrm{L}^{-1}$ ) (Pérez-Carrera et al., 2007) and linear alkylbenzene sulphonates (LAS) $\left(81 \mu \mathrm{g} \mathrm{L}^{-1}\right)$ (Lara-Martín et al., 2008) in surface waters adjacent to the discharge outlet.

TCS and MTCS are hydrophobic compounds (log $K_{o w}$ and $\log$ $K_{o c}>4$ ) showing high affinity for the particulate matter (Chen et al., 2011), which may be removed from the water column by sedimentation. The presence of both compounds was detected in surface sediment samples along the estuary. Table 2 shows their concentrations from the mouth of the river (station G1) up to $100 \mathrm{~m}$ upstream the WWTP effluent (station G13). The organic carbon content is also presented, being less than $2 \%$ in these sediment samples and relatively constant between sampling stations. TCS levels were between 0.3 and $9.6 \mathrm{ng} \mathrm{g}^{-1}$, within the same concentration range as that reported in sediments from other Spanish aquatic systems (Agüera et al., 2003). The maximum concentration $\left(9.6 \mathrm{ng} \mathrm{g}^{-1}\right)$ was detected at station G11, where there is a small dam located a few hundred meters downstream the WWTP effluent that facilitates the sedimentation of suspended solids. A secondary maximum ( $>5 \mathrm{ng} \mathrm{g}^{-1}$ ) took place between stations $\mathrm{G} 2$ and G5, surrounded by El Puerto de Santa María. There is a previous study (Lara-Martín et al., 2008) on surfactants, excellent sewage

Table 1

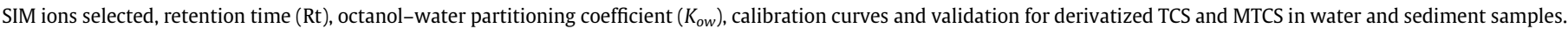

\begin{tabular}{|c|c|c|c|c|c|c|c|c|c|}
\hline \multirow[t]{2}{*}{ Compounds } & \multirow[t]{2}{*}{$m / z$} & \multirow[t]{2}{*}{$R t(\min )$} & \multirow[t]{2}{*}{$\log K_{o w}$} & \multicolumn{2}{|l|}{ Water samples } & \multicolumn{2}{|l|}{ Sediment samples } & \multicolumn{2}{|l|}{ RSD } \\
\hline & & & & Calibration curve & $R^{2}$ & Calibration curve & $R^{2}$ & Repeatability & Reproducibility \\
\hline TCS-TBDMS & 345,347 & 24.86 & 4.7 & $y=6 \times 10^{-7} x-0.0436$ & 0.9942 & $y=7 \times 10^{-8} x+0.0737$ & 0.9985 & 15.22 & 9.36 \\
\hline MTCS & 302,304 & 20.93 & 5.2 & $y=4 \times 10^{-7} x+0.0967$ & 0.9961 & $y=1 \times 10^{-7} x+0.0288$ & 0.9979 & 4.17 & 8.89 \\
\hline
\end{tabular}


Table 2

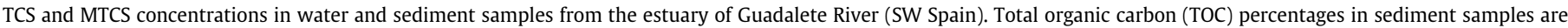
also shown (n.d. = non-detected).

\begin{tabular}{|c|c|c|c|c|c|c|}
\hline Water (sampling time) & $\mathrm{TCS}\left[\mathrm{ng} \mathrm{L}^{-1}\right]$ & MTCS [ng L ${ }^{-1}$ ] & Sediment (sampling station) & $\mathrm{TCS}\left[\mathrm{ng} \mathrm{g}^{-1}\right]$ & MTCS [ng g ${ }^{-1}$ ] & TOC (\%) \\
\hline 07:30 & 27 & 97 & $\mathrm{Gl}$ & 2.2 & 1.8 & 1.7 \\
\hline 08:30 & 41 & 52 & G2 & 5.4 & 0.8 & 1.1 \\
\hline 09:30 & 281 & 191 & G3 & 3.7 & 0.9 & 0.4 \\
\hline $10: 30$ & 120 & 27 & G4 & 3.8 & 0.6 & 1.0 \\
\hline $11: 30$ & 96 & 91 & G5 & 5.1 & 1.5 & 1.2 \\
\hline $13: 30$ & 78 & 52 & G6 & 3.6 & 0.5 & 0.7 \\
\hline $14: 30$ & 93 & 93 & G7 & 1.8 & 0.9 & 0.5 \\
\hline $15: 30$ & 142 & 107 & G8 & 0.3 & 0.4 & 1.6 \\
\hline $16: 30$ & 246 & 150 & G9 & 4.9 & n.d. & 2.0 \\
\hline $17: 30$ & 310 & 95 & G10 & 7.9 & n.d. & 1.2 \\
\hline \multirow[t]{3}{*}{$18: 30$} & 130 & 94 & G11 & 9.6 & n.d. & 0.8 \\
\hline & & & G12 & 7.8 & n.d. & 0.9 \\
\hline & & & G13 & 2.5 & n.d. & 1.1 \\
\hline
\end{tabular}

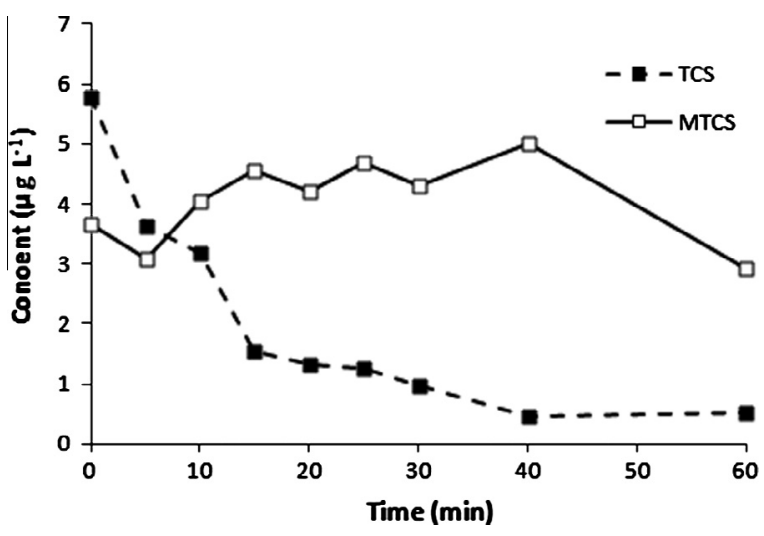

Fig. 6. Photodegradation kinetics of TCS and MTCS in seawater.

markers, showing exactly the same trend and explaining the distribution of organic contaminants in the estuary as a combination of wastewater discharges coming from the WWTP upstream and the town by the mouth of the river. On the other hand, MTCS was found at lower concentrations than TCS (usually below $1 \mathrm{ng} \mathrm{g}^{-1}$ ) and only between stations G1 and G8. This metabolite may be produced by transformation processes taking place in the WWTP and/ or in the water column (Lindström et al., 2002). We hypothesize that the presence of MTCS in the estuary was mostly due to in situ degradation of triclosan as its degradation product was not detected in sediments surrounding the WWTP effluent discharge. In this sense, several biodegradation experiments (under aerobic and anaerobic conditions) using water and sediments from this area are currently under way.

\section{Conclusions}

The proposed method allows for the simultaneous extraction and determination of triclosan and its main biotransformation product, MTCS, in both aqueous and solid environmental matrices at sub-ppb levels by using SBSE. This technique is easy to use and sensitive, with LODs that are satisfactory for both analytes and are in the same order than other studies (Casas-Ferreira et al., 2011) relying on more conventional approaches such as SPE and Soxhlet extraction. Advantages of SBSE include cost effectivity, less solvent consumption, less sample manipulation and faster analysis times. Also, the analysis with GC offers better resolution that high performance liquid chromatography (HPLC) analysis of TCS (Chu and Metcalfe, 2007). Although less sensitive, liquid desorption (LD) is also presented here as an alternative choice to use SBSE followed by thermal desorption (TD) when TD units are not available. Moreover, this work also shows some of the first available data on the distribution of TCS and MTCS in estuarine settings. These data obtained in real samples confirm the effectiveness of this method. Further research, however, is recommended in order to improve our knowledge on the environmental behavior of these substances as well as the quality of future environmental risk assessments.

\section{Acknowledgements}

This study has been supported by two Regional Research Projects (RNM 5417 and RNM 6613) and a FPI fellowship funded by the "Consejería de Economía, Innovación y Ciencia" of the Regional Government of Andalusia.

\section{References}

Agüera, A., Fernández-Alba, A.R., Piedra, L., Mézcua, M., Gómez, M.J., 2003. Evaluation of triclosan and biphenylol in marine sediments and urban wastewaters by pressurized liquid extraction and solid phase extraction followed by gas chromatography mass spectrometry and liquid chromatography mass spectrometry. Anal. Chim. Acta. 480 (2), 193-205.

Azzouz, A., Souhail, B., Ballesteros, E., 2010. Continuous solid-phase extraction and gas chromatography-mass spectrometry determination of pharmaceuticals and hormones in water samples. J. Chromatogr. A 1217 (17), 2956-2963.

Balmer, M.E., Poiger, T., Droz, C., Romanin, K., Bergqvist, P.-A., Müller, M.D., Buser, H.R., 2004. Occurrence of methyl triclosan, a transformation product of the Bactericide Triclosan, in fish from various lakes in Switzerland. Environ. Sci. Technol. 38 (2), 390-395.

Baltussen, E., Sandra, P., David, F., Cramers, C., 1999. Stir bar sorptive extraction (SBSE), a novel extraction technique for aqueous samples: theory and principles. J. Microcolumn. Sep. 11, 737-747.

Beltran, J., Lopez, F.J., Cepria, O., Hernández, F., 1998. Solid-phase microextraction for quantitative analysis of organophosphorus pesticides in environmental water samples. J. Chromatogr. A 808 (1-2), 257-263.

Bester, K., 2005. Fate of triclosan and triclosan-methyl in sewage treatment plants and surface waters. Arch. Environ. Contam. Toxicol. 49 (1), 9-17.

Buth, J.M., Steen, P.O., Sueper, C., Blumentritt, D., Vikesland, P.J., Arnold, W.A., Mcneill, K., 2010. Dioxin photoproducts of triclosan and its chlorinated derivatives in sediment cores. Environ. Sci. Technol. 44 (12), 4545-4551.

Canosa, P., Rodríguez, I., Rubí, E., Cela, R., 2005. Optimization of solid-phase microextraction conditions for the determination of triclosan and possible related compounds in water samples. J. Chromatogr. A 1072 (1), 107-115.

Canosa, P., Pérez-Palacios, D., Garrido-López, A., Tena, M.T., Rodríguez, I., Rubí, E., Cela, R., 2007. Pressurized liquid extraction with in-cell clean-up followed by gas chromatography-tandem mass spectrometry for the selective determination of parabens and triclosan in indoor dust. J. Chromatogr. A 1161 (1-2), 105-112.

Cantwell, M.G., Wilson, B.A., Zhu, J., Wallace, G.T., King, J.W., Olsen, C.R., Burgess, R.M., Smith, J.P. 2010. Temporal trends of triclosan contamination in dated sediment cores from four urbanized estuaries: evidence of preservation and accumulation. Chemosphere 78 (4), 347-352.

Casas-Ferreira, A.M., Möder, M., Fernández-Laespada, M.E., 2011. Stir bar sorptive extraction of parabens, triclosan and methyl triclosan from soil, sediment and sludge with in situ derivatization and determination by gas chromatographymass spectrometry. J. Chromatogr. A 1218, 3837-3844. 
Chen, X., Nielsen, J.L., Furgal, K., Liu, Y., Lolas, I.B., Bester, K., 2011. Biodegradation of triclosan and formation of methyl-triclosan in activated sludge under aerobic conditions. Chemosphere 84 (4), 452-456.

Chu, S., Metcalfe, C.D., 2007. Simultaneous determination of triclocarban and triclosan in municipal biosolids by liquid chromatography tandem mass spectrometry. J. Chromatogr. A 1164, 212-218.

Ciba (Chemische Industrie Basel) Specialty Chemical, 1998 Facts Sheet - PEC (Predicted Environmental Concentrations) Calculation of Triclosan; Basel, Switzerland.

Cottell, A., Denyer, S.P., Hanlon, G.W., Ochs, D., Maillard, J.Y., 2009. Triclosantolerant bacteria: changes in susceptibility to antibiotics. J. Hosp. Infect. 72 (1), 71-76.

Council Directive, 76/768/EEC (July 27th, 1976).

Cueva-Mestanza, R., Sosa-Ferrera, Z., Torres-Padrón, M.E., Santana-Rodríguez, J.J., 2008. Preconcentration of pharmaceuticals residues in sediment samples using microwave assisted micellar extraction coupled with solid phase extraction and their determination by HPLC-UV. J. Chromatogr. B 863 (1), 150-157.

El Rayis, O.A., 1985. Re-assessment of the titration method for determination of organic carbon in recent sediments. Rapp. Commun. Int. Mer. Medit. 29, 45-47.

Environmental Protection Agency (EPA), (<www.epa.gov/oppsrrd1/REDs/ factsheets/triclosan_fs.htm>)

Fernandes, M., Shareef, A., Kookana, R., Gaylard, S., Hoare, S., Kildea, T., 2011. The distribution of triclosan and methyl-triclosan in marine sediments of Barker Inlet, South Australia. J. Environ. Monitor. 13 (4), 801-806.

Fiss, E.M., Rule, K.L., Vikesland, P.J., 2007. Formation of chloroform and other chlorinated byproducts by chlorination of triclosan-containing antibacterial products. Environ. Sci. Technol. 41 (7), 2387-2394.

Gilart, N., Miralles, N., Marce, R.M., Borrull, F., Fontanals, N., 2013. Novel coatings for stir bar sportive extraction to determine pharmaceuticals and personal care products in environmental waters by liquid chromatography and tandem mass spectrometry. Anal. Chim. Acta 774, 51-60.

Giordano, A., Fernández-Franzón, M., Ruiz, M.J., Font, G., Picó, Y., 2009. Pesticide residue determination in surface waters by stir bar sorptive extraction and liquid chromatography/tandem mass spectrometry. Anal. Bional. Chem. 393, 1733-1743.

Göbel, A., Thomsen, A., McArdell, C.S., Alder, A.C., Giger, W., Theiß, N., Löffler, D., Ternes, T.A., 2005. Extraction and determination of sulfonamides, macrolides, and trimethoprim in sewage sludge. J. Chromatogr. A 1085 (2), 179-189.

Heidler, J., Halden, R.U., 2007. Mass balance assessment of triclosan removal during conventional sewage treatment. Chemosphere 66 (2), 362-369.

Kantiani, L., Farré, M., Asperger, D., Rubio, F., González, S., López de Alda, M.J., Petrovic, M., Shelver, W.L., Barceló, D., 2008. Triclosan and methyl-triclosan monitoring study in the northeast of Spain using a magnetic particle enzyme immunoassay and confirmatory analysis by gas chromatography-mass spectrometry. J. Hydrol. 361 (1-2), 1-9.

Kawaguchi, M., Ito, R., Honda, H., Endo, N., Okanouchi, N., Saito, K., Seto, Y., Nakazawa, H., 2008. Stir bar sorptive extraction and thermal desorption-gas chromatography-mass spectrometry for trace analysis of triclosan in water sample. J. Chromatogr. A 1206 (2), 196-199.

Kuster, M., López de Alda, M.J., Hernando, M.D., Petrovic, M., Martín-Alonso, J. Barceló, D., 2008. Analysis and occurrence of pharmaceuticals, estrogens, progestogens and polar pesticides in sewage treatment plant effluents, river and drinking water in the Llobregar river basin (Barcelona, Spain). J. Hydrol. 358 (1-2), 112-123.

Lara-Martín, P.A., González-Mazo, E., 2009. PFE in the analysis of POPs in environmental samples. Methods and new trends in environmental, biological, food analysis of persistent organic pollutants (POPs). A review. Res. Signpost, 59-81.

Lara-Martín, P.A., Gómez-Parra, A., González-Mazo, E., 2006. Simultaneous extraction and determination of anionic surfactants in waters and sediments. J. Chromatogr. A 1114 (2), 205-210.

Lara-Martín, P.A., Gómez-Parra, A., González-Mazo, E., 2008. Sources, transport and reactivity of anionic and non-ionic surfactants in several aquatic ecosystems in SW Spain: a comparative study. Environ. Pollut. 156 (1), 36-45.

Lindström, A., Buerge, I.J., Poiger, T., Bergqvist, P.-A., Müller, M.D., Buser, H.-R., 2002. Occurrence and environmental behavior of the Bactericide Triclosan and its methyl derivative in surface waters and in wastewater. Environ. Sci. Technol. 36 (11), 2322-2329.

Lozano, N., Rice, C.P., Ramírez, M., Torrents, A., 2010. Fate of triclosan in agricultural soils after biosolid applications. Chemosphere 78 (6), 760-766.

Miller, T.R., Heidler, J., Chillrud, S.N., DeLaquil, A., Ritchie, J.C., Mihalic, J.N., Bopp, R., Halden, R.U., 2008. Fate of triclosan and evidence for reductive dechlorination of triclocarban in estuarine sediments. Environ. Sci. Technol. 42 (12), 4570-4576.

Pedrouzo, M., Borrull, F., Marce, R.M., Pocurull, E., 2010. Stir-bar-sorptive extraction and ultra-high-performance liquid chromatography-tandem mass spectrometry for simultaneous analysis of UV filters and antimicrobial agents in water samples. Anal. Bioanal. Chem. 397 (7), 2833-2839.

Pérez-Carrera, E., León-León, V.M., Gómez-Parra, A., González-Mazo, E., 2007. Simultaneous determination of pesticides, polycyclic aromatic hydrocarbons and polychlorinated biphenyls in seawater and interstitial marine water samples, using stir bar sorptive extraction-thermal desorption-gas chromatography-mass spectrometry. J. Chromatogr. A 1170 (1-2), 82-90.

Petrovic, M., Lacorte, S., Viana, P., Barceló, D., 2002. Pressurized liquid extraction followed by liquid chromatography-mass spectrometry for the determination of alkylphenolic compounds in river sediment. J. Chromatogr. A 959 (1-2), 1523.

Prieto, A., Basauri, O., Rodil, R., Usobiaga, A., Fernández, L.A., Etxebarria, N., Zuloaga., 2010. Stir-bar sorptive extraction: a view on method optimisation, novel applications, limitations and potential solutions. J. Chromatogr. A 1217 (16), 2642-2666.

Quintana, J.B., Rodil, R., Muniategui-Lorenzo, S., López-Mahía, P., prada-Rodríguez, D., 2007. Multiresidue analysis of acidic and polar organic contaminants in water samples by stir-bar sorptive extraction-liquid desorption-gas chromatography-mass spectrometry. J. Chromatogr. A 1174 (1-2), 27-39.

Sánchez-Brunete, C., Miguel, E., Albero, B., Tadeo, J.L., 2010. Determination of triclosan and methyl triclosan in environmental solid samples by matrix solidphase dispersion and gas chromatography-mass spectrometry. J. Sep. Sci. 33 (17-18), 2768-2775.

Silva, A.R.M., Nogueira, J.M.F., 2008. New approach on trace analysis of triclosan in personal care products, biological and environmental matrices. Talanta 74 (5), 1498-1504.

Ternes, T.A., Meisenheimer, M., McDowell, D., Sacher, F., Brauch, H.J., Gulde, B.H., Preuss, G., Wilme, U., Seibert, N.Z., 2002. Removal of pharmaceuticals during drinking water treatment. Environ. Sci. Technol. 36 (17), 3855-3863.

Wu, J.-L., Lam, N.P., Martens, D., Kettrup, A., Cai, Z., 2007. Triclosan determination in water related to wastewater treatment. Talanta 72 (5), 1650-1654.

Zaroogian, G.E., Pesche, G., Morrison, G., 1969. Formulation of an artificial sea water media suitable for oyster larvae development. Am. Zool. 9, 1144.

Zhao, J.-L., Ying, G.-G., Liu, Y.-S., Chen, F., Yang, J.-F., Wang, L., 2010. Occurrence and risks of triclosan and triclocarban in the Pearl River system, South China: from source to the receiving environment. J. Hazard. Mater. 179 (1-3), 215-222. 